\title{
Rockfall Hazard Analyses and Rockfall Protection along the Adriatic Coast of Croatia
}

\author{
Željko Arbanas ${ }^{1}$, Mirko Grošić ${ }^{2}$, Dalibor Udovič ${ }^{2}$ and Snježana Mihalić ${ }^{3}$ \\ 1. Department of Hydrotechnics and Geotechnics, Faculty of Civil Engineering, University of Rijeka, Rijeka (RI) 51000, Croatia \\ 2. Geotech Ltd., Rijeka (RI) 51000, Croatia \\ 3. Department of Geology and Geological Engineering, Faculty of Mining, Geology and Petroleum Engineering, University of Zagreb, \\ Zagreb (ZG) 10000, Croatia
}

\begin{abstract}
During the last decade, large rockfalls occurred on the steep limestone slopes along the Adriatic Coast of Croatia, causing injury to people and serious damage to buildings and traffic facilities. The rockfalls along the limestone slopes were caused by unfavorable characteristics of the rock mass, weathering in combination with heavy rainfall and artificial influences during highway construction. Rockfall protection projects were conducted to protect human lives and facilities from future rockfalls. The rockfall protection program started with rockfall hazard analyses to identify the potential of rockfalls to occur and the potential consequences. At the locations of hazards where related risks were determined, detailed field investigations were conducted. Based on the indentified characteristics of potentially unstable rock masses, analyses of movement and resulting pathways were conducted. The trajectories, impact energy and the height of bouncing are dependent on slope geometry, slope surface roughness and rockfall block characteristics. Two protection measure approaches were adopted: prevention of rockfalls by removing potentially unstable rock mass or installation of rock mass support systems and suspending running rockfall masses with rockfall protection barriers. In this paper, rockfall hazard determination, rockfall analyses and rockfall protection designs for rockfall protection systems at selected locations on the limestone slopes along the Adriatic coast of Croatia are presented.
\end{abstract}

Key words: Rockfall, rockfall hazard, rockfall hazard analyses, rockfall protection measures, rockfall protection barriers, rock mass support.

\section{Introduction}

During the last decade, large rockfalls occurred on the steep limestone slopes along the Adriatic Coast of Croatia, causing serious damage to buildings and traffic facilities, injury to people and delayed traffic on roads, as shown in Fig. 1. Settlements and transportation facilities in coastal areas with steep rock slopes are vulnerable to rockfalls. In recent years, a number of highways have been or are scheduled to be built in the coastal regions of Croatia that carry significant risk of increasing rockfall hazard events.

Corresponding author: Željko Arbanas, associate professor, research fields: rock mechanics, weak rocks, flysch, excavation in rock mass, rock slope stability, rock mass support systems, landslides, remediation of landslides, monitoring of landslides. E-mail: zeljko.arbanas@gradri.hr.
The rockfall events along the limestone slopes were caused by unfavorable rock mass characteristics, rock mass weathering in combination with heavy rainfalls and the influence of improper slope interventions during highway construction. The rockfall protection projects were conducted to ensure the protection of human lives and facilities from future rockfalls. The rockfall protection projects started with rockfall hazard analyses to identify the potential of rockfalls to occur and the potential consequences, i.e., risk. At the locations where hazards with related risk were determined, detailed field investigations were provided. Based on the indentified characteristics of potentially unstable rock mass blocks, analyses of the motion and resulting pathways of rockfalls were conducted. Rockfall trajectories, impact energy and height of bouncing depend on the slope geometry, slope surface 

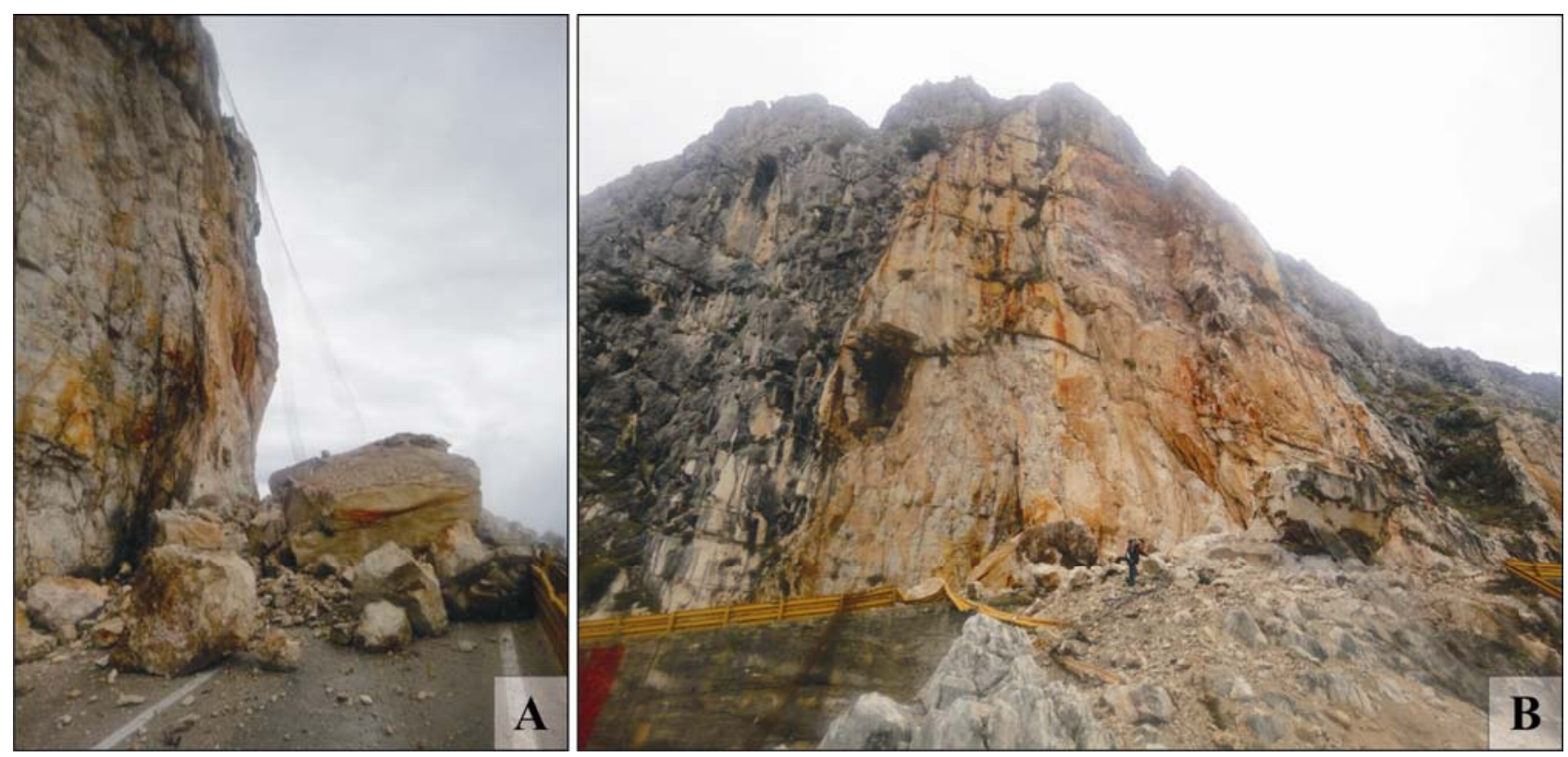

Fig. 1 Rockfall on a regional road near the City of Makarska, Croatia. (A) Picture of fallen limestone blocks. (B) A view of the cut. The light color indicates the previous position of the fallen rock mass (October 2010).

roughness and rockfall block characteristics. Based on these analyses, rockfall protection measures were designed. Two design approaches were adopted: (1) prevention of rockfall by removing potentially unstable rock mass or by installing a rock mass support system and (2) suspending the running rockfall mass with rockfall protection barriers. In this paper, the Croatian experiences on rockfall hazard determination, rockfall analyses and applied protection designs at particular locations along the Adriatic coast of Croatia are presented.

\section{Rockfall Hazard Assessments}

A rockfall is defined as a rock mass that has detached from a steep slope or cliff along a surface with little or no shear displacement and descends most of its distance through the air [1]. Once a rock block has detached from the steep slope, it will free fall, topple, bounce, roll or slide along the slope surface at a high speed, which can cause significant damages to the facilities at the foot of the slope [2]. A potential rockfall can be composed of either rock blocks cut by discontinuities and free faces or boulders and rock fragments on a soil or talus slope surface. Rockfalls can be caused by many factors, including unfavorable rock structure (discontinuities), adverse ground water-related conditions, poor blasting practices during original construction or reconstruction, climatic changes, weathering and tree leveling [3]. Seismic ground motions caused by earthquakes can also be an important triggering factor.

A rockfall hazard occurs when a rock block falls into an area where there are human activities or construction and causes damages and/or fatalities. The rockfall hazard is a combination of a source, a triggering event and the pathway to the at-risk object [4]. The source may be an engineered or a natural slope defined by the appropriate topography and geology of the slope. The geological factors that directly influence a rockfall hazard are the characteristics of the rock mass discontinuities and the rock strength. The spacing between discontinuities defines the size and shape of the rock block, and discontinuity orientation defines the type of initial instability mechanism (sliding, toppling). The rock strength influences the type of movement along the slope surface (bouncing, rolling, sliding). The slope surface between the source and the at-risk object is defined as a pathway [4], and the travel 
distance along a pathway depends on factors such as the size of the block, the dip of the slope, the composition and the asperity of the slope surface. To determine the rock travel distance, different computer-modeling software was developed using parameters that can influence the type of movement and the rock travelling distance.

The areas of potential rockfall pathways define the potential objects at risk. The rockfall analysis and exposition of the risk is a very complex operation, requiring an exact assessment of the hazard elements (triggering mechanisms and the pathway parameters) and the vulnerability of the objects at risk. Several authors have proposed different methods for predicting the pathways of rockfalls [5-11]. These methods identify the pathways of rockfalls using factors for evaluating rockfall risk: the height of the rock bounce and the velocity of the rock blocks. Most of these methods were developed for evaluating rockfall risk to vehicles along roads and include the following factors: the vehicle speed and length, the available decision sight distance, the traffic volume, the length of the landslide risk section of the route, the number of occupants in a vehicle, and the type of vehicle [12].

Different hazard rating systems are used for rockfall hazard determination on large areas near roads to identify the most hazardous rock slopes. On the basis of early works on rockfall hazard slope ratings, Pierson et al. [13] developed the Oregon Rockfall Hazard Rating System (RHRS) based on an evaluation of nine different categories. These nine categories include all the elements regarding the rockfall hazard (slope height, geological characterization of the slope, volume of rockfall/block size, climate, the presence of water on the slope and rockfall history) and the vehicle vulnerability (ditch effectiveness, average vehicle risk, percent of decision sight distance and roadway width).

Budetta [12] modified the rockfall hazard rating system developed by Pierson et al. [13]. The modification's presumption was that some qualitative categories make the appraisals too subjective [2]. The ratings for the categories of ditch effectiveness, geologic characteristic, volume of rockfall/block size, climate, water circulation and rockfall history are explained more easily and objectively. In the modified method, Romana's Slope Mass Rating (SMR) [14] for slope instability hazard evaluation was introduced to improve the estimate of the geologic characteristics. Slope Mass Rating (SMR) is developed from the Rock Mass Rating classification [15] by excluding a factor depending on the joint-slope relationship and adding a factor depending on the method of excavation. The risk degree, based on Budetta's modification, depends not only on the characteristics of rockfall itself but also on the risk-affected elements. The properties, size and shape of the rock block and the shape and the surface material conditions of the slope should be considered in rockfall hazard assessment.

Similar systems have been developed and adopted by organizations in other countries, but an appropriate rockfall hazard rating system approach was never developed by Croatian organizations incorporating local rockfall conditions. Using a rockfall hazard rating system was introduced after the occurrence of rockfalls with fatalities and serious damages to prevent further rockfall hazards. In these cases, the existing rockfall hazard rating systems were used, based on experiences from neighboring countries, especially Italy. The rockfall protection projects were conducted to protect human lives and facilities from future rockfalls. The rockfall protection projects started with rockfall hazard analyses to identify the potential of rockfalls occurring and the potential accidental consequences, i.e., risk.

At locations where hazards with related risk were determined, detailed field investigations were provided. The field investigations were based on direct field-mapping techniques, and potentially unstable zones and rock blocks on the slopes were determined. Field investigations were carried out on the rock slope areas to determine the most influential geological and geotechnical characteristics of the rock material subject to rockfalls and to assess the most significant factors 
that can affect slope instability. The detailed objectives of the field investigations are as follows [16, 17]: (1) to describe the most relevant factors contributing to the slope instability hazards at the site; (2) to collect discontinuity data to obtain sufficient information regarding the geological structures and discontinuity patterns and the effect of their orientation on modes of failure (planar, wedge or topple failure analysis); (3) to determine the geometry of the rock cut in different areas to apply the rock fall simulation analysis to the impact of falling rocks on the highway; (4) to apply a rockfall hazard rating system; and (5) to develop a mitigation strategy for each section of the highway and to develop alternative solutions and designs to minimize future problems.

Based on the identified characteristics of potentially unstable rock mass blocks, deterministic analyses of the motion and the resulting pathways of rockfalls were conducted. The trajectories, impact energy and height of bouncing are dependent on the slope geometry, slope surface roughness and rockfall block characteristics. Based on the data, relatively crude rockfall simulation models are capable of producing reasonably accurate predictions of the rockfall trajectories and travel pathways [18-21]. Most of these rockfall models include a Monte Carlo simulation technique to vary the parameters included in the analysis. This technique is similar to the random process of throwing dice, one for each parameter being considered in the rockfall analysis [8].

Based on these analyses, rockfall protection measures were designed. Two design approaches were adopted: (1) the prevention of rockfalls by removing potentially unstable rock mass or by installing rock mass support systems and (2) the reduction of rockfall mass energy and suspension of running rockfall mass using rockfall protection barriers.

Where it is possible to detect possible rockfall hazards using direct field-mapping techniques, rockfall prevention projects are recommended and advisable. The prevention measures can enable the elimination of hazards by removing potentially unstable rock mass from the slope or by constructing an adequate rock mass support system. Removing the possible unstable rock mass from the slope could be more expensive than appropriate support construction, especially on steep slopes. In that case, support systems using high-capacity steel meshes or reinforced concrete in combination with rock bolts could ensure the appropriate stability of rock slope against rockfall.

When it is not possible to detect or prevent all possible rockfalls, an approach to reduce or/and restrain rockfall consequences can be adopted. Approaches to reduce or/and restrain rockfall energy and suspend running rockfall mass are well known in the geotechnical engineering praxis, using berms and rockheads on the slope, ditches and fills in the toe of the slope and catch fences and protection barriers at different positions of the slope [8, 22, 23]. Catch fences or barrier fences in common use are estimated to have an energy absorption capacity of more than $100 \mathrm{~kJ}$. This is equivalent to a $250 \mathrm{~kg}$ rock moving at velocity of about $20 \mathrm{~m} / \mathrm{s}$. More robust protection barriers, with an energy absorbing capacity of up to $5000 \mathrm{~kJ}$ and height of up to $8 \mathrm{~m}$, have been used as a rockfall protection at some locations in Croatia.

\section{Rockfall Hazard Analysis and Rockfall Protection Experiences in Croatia}

The investigation of rockfall hazards and rockfall hazard mitigation requirements in Croatia were increased during the last decade after large rockfalls occurred on the steep limestone slopes along the Adriatic Coast of Croatia (Fig. 2A).

These rockfalls caused injury to people and serious damage to buildings, especially traffic facilities. In recent years, a number of highways have been or are scheduled to be built in the coastal region of Croatia that carry significant risk of increasing rockfall hazard events. The main factors leading to rockfall events along the limestone slopes are unfavorable rock mass characteristics during heavy rain periods and the 


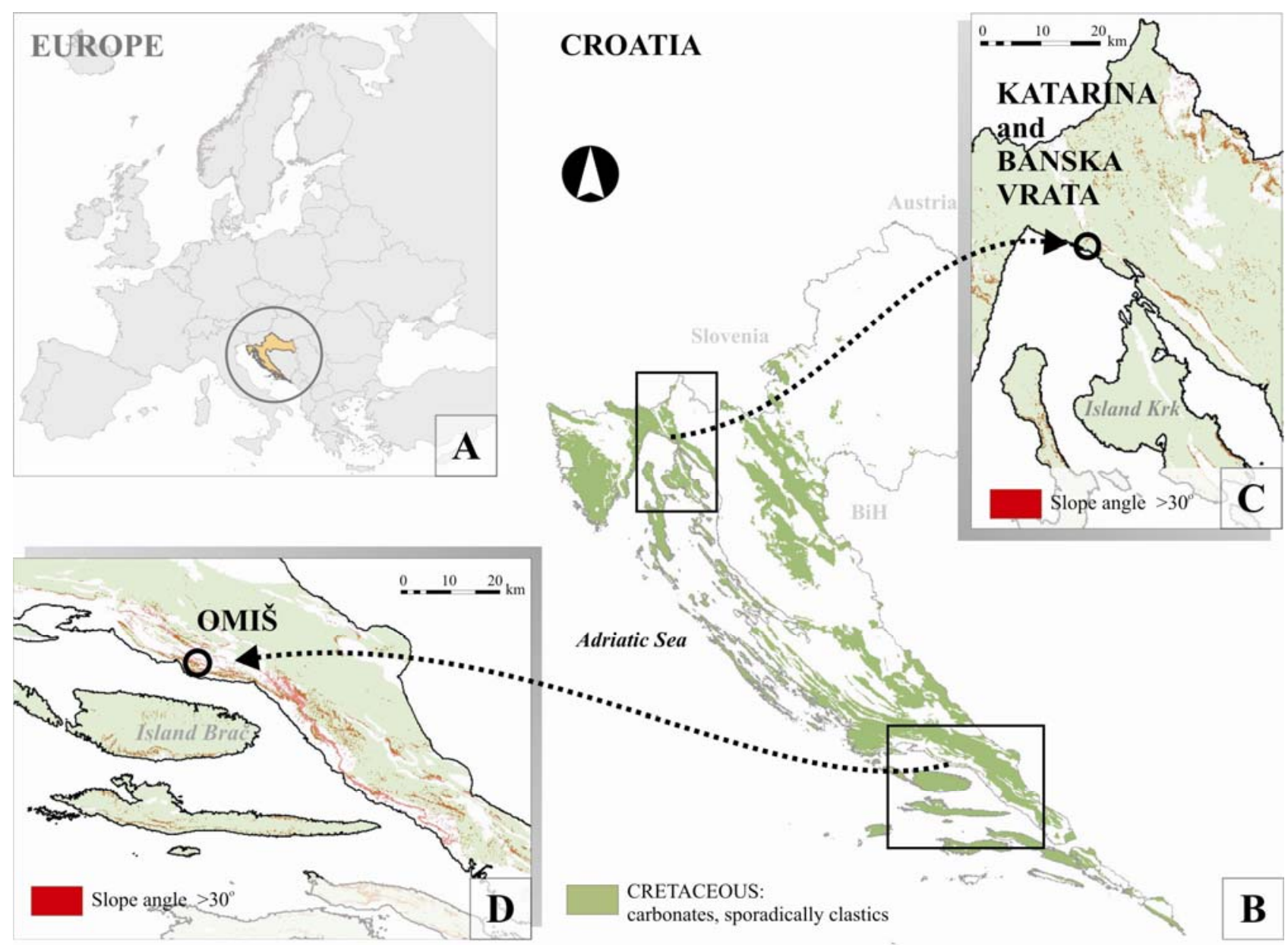

Fig. 2 Location maps: (A) Geographic location of the Republic of Croatia; (B) Spatial distribution of Cretaceous carbonate rock units in Croatia; (C) Enlarged map with locations of the Katarina and Banska Vrata rockfalls; (D) Enlarged map with locations of rockfalls around Omiš. Dark color represents areas in which slope angles $>30^{\circ}$ were computed from the $25 \mathrm{~m} \times 25$ m DEM.

influence of improper interventions in slopes during highway construction.

Most of the occurred rockfalls were registered on the engineered cuts and natural slopes near old roads. The consequences of these rockfalls induced a systematic approach to reduce or/and restrain the rockfall hazards. Old road slopes, where different types of rockfalls had been registered in the past, were subjected to rockfall hazard analysis, and on the basis of these analyses, rockfall protection projects were conducted. The significant advancement in rockfall hazard analysis and rockfall protection over the last ten years resulted from the design and construction of new roads and highways in Croatia. An appropriate rockfall hazard rating system incorporating local rockfall conditions in
Croatia was never developed, and there are no official recommendations for rockfall hazard analysis. Under these conditions, scientists and geotechnical engineers used existing rockfall hazard rating systems based on experiences from neighboring countries.

The new requirements for rock mass properties and rock mass behavior for rockfall hazard analysis were obtained during field investigations and the construction of highways on steep limestone slopes along the Adriatic coast around the City of Rijeka, in Lika and Dalmatia. Any higher highway cut in the steep slope required significant slope stability and rockfall hazard analyses. It was also necessary to provide appropriate analyses of possible constructions influences on rockfall hazards. All these analyses 
significantly depended on geological conditions at particular sites.

Rockfall phenomena in Croatia frequently occur in carbonate rocks that belong to the Adriatic Carbonate Platform (AdCP), the largest Mesozoic carbonate platforms of the Perimediterranean region [24]. Its deposits outcrop in Italy, Slovenia, Croatia, Bosnia and Herzegovina, Serbia and Montenegro and Albania. A major part of the carbonate succession outcrops in the Croatian part of Karst Dinarides. Only deposits ranging from the top of the Lower Jurassic to the top of the Cretaceous can be attributed to the AdCP. The deposits formed during the $125 \mathrm{My}$ of the platform's existence, and the thickness is variable (between 3500 and 5000 m). AdCP margins are almost completely covered. The SW margin of the platform is covered by modern Adriatic Sea deposits and can only be studied by geophysical methods and the analysis of offshore wells. In contrast, the NE platform margin is partly exposed, although its major parts are covered by overthrusted Paleozoic-Triassic deposits, Late CretaceousPaleogene flysch or Neogene and Quaternary deposits.

The distribution of Cretaceous carbonate rock units (sporadically clastics) is shown in Fig. 2B. Carbonate rocks, which constitute the main part of Croatian Karst, cover approximately $23 \%$ of the surface area of Croatia.

The formation of Croatian Karst is caused by tectonic processes followed by the weathering of carbonate rocks [25]. Engineering geological conditions in karstified carbonate rock masses is strongly influenced by the degree of weathering and the distribution of typical morphological karst features (size and frequency). Generally, the thickness of superficial deposits is thin, and rocks are mainly covered by topsoil.

According to the previously discussed approaches to rockfall prevention, reduction of rockfall mass energy and suspending of running rockfall mass, three significant projects will be presented: rockfall hazard reduction using rockfall protection barriers during construction of the Brzet Tunnel near Omiš (Fig. 2D) and the Katarina Tunnel near Rijeka and rockfall prevention by installing a rock mass support system on the Louisiana Road at the Banska Vrata location near the City of Rijeka (Fig. 2C).

\section{Rockfall Protection Barriers at the Brzet Tunnel near the City of Omiš}

The city of Omiš is situated on the Adriatic coast at the toe of high limestone cliffs and it is very exposed to high rockfall hazards, with recent rockfall events (Fig. $3 \mathrm{~A})$. The main road along the coast passes through the city of Omiš. Construction of a new bypass motorway subparallel with the existing road was recently initiated. The steep slopes above the city of Omiš provided demanding conditions for the design and construction of the motorway, tunnels and viaducts. Construction of the Brzet Tunnel was started in the spring of 2008, but immediately after construction began, it was halted because of the perceived rockfall hazard. On the rock slope surface below the motorway route, many single, possible unstable, rock blocks were identified (Fig. 3B). The volumes of these blocks were between 0.5 and 20 $\mathrm{m}^{3}$, but some blocks had a volume of $150 \mathrm{~m}^{3}$. The rockfall hazard, the potential detachment of these blocks, was identified after the seismic effects caused by blasting induced small rockfalls.

Field investigations consisted of detecting and geodetic surveying of potentially unstable blocks: all potentially unstable blocks in the influence area were marked, spatial coordinates of the blocks were identified, their volume and shape were described and classifications of the possible instability of the blocks were estimated. Almost 150 potentially unstable blocks were found and marked (Fig. 4A). Based on the indentified characteristics of possible unstable blocks, deterministic analyses of motion and the resulting pathways were performed. A two-dimensional slope profile was used for the rockfall simulations. The rockfall simulations were conducted on the eight most critical profiles. The simulations were modeled as $2 \mathrm{D}$ 

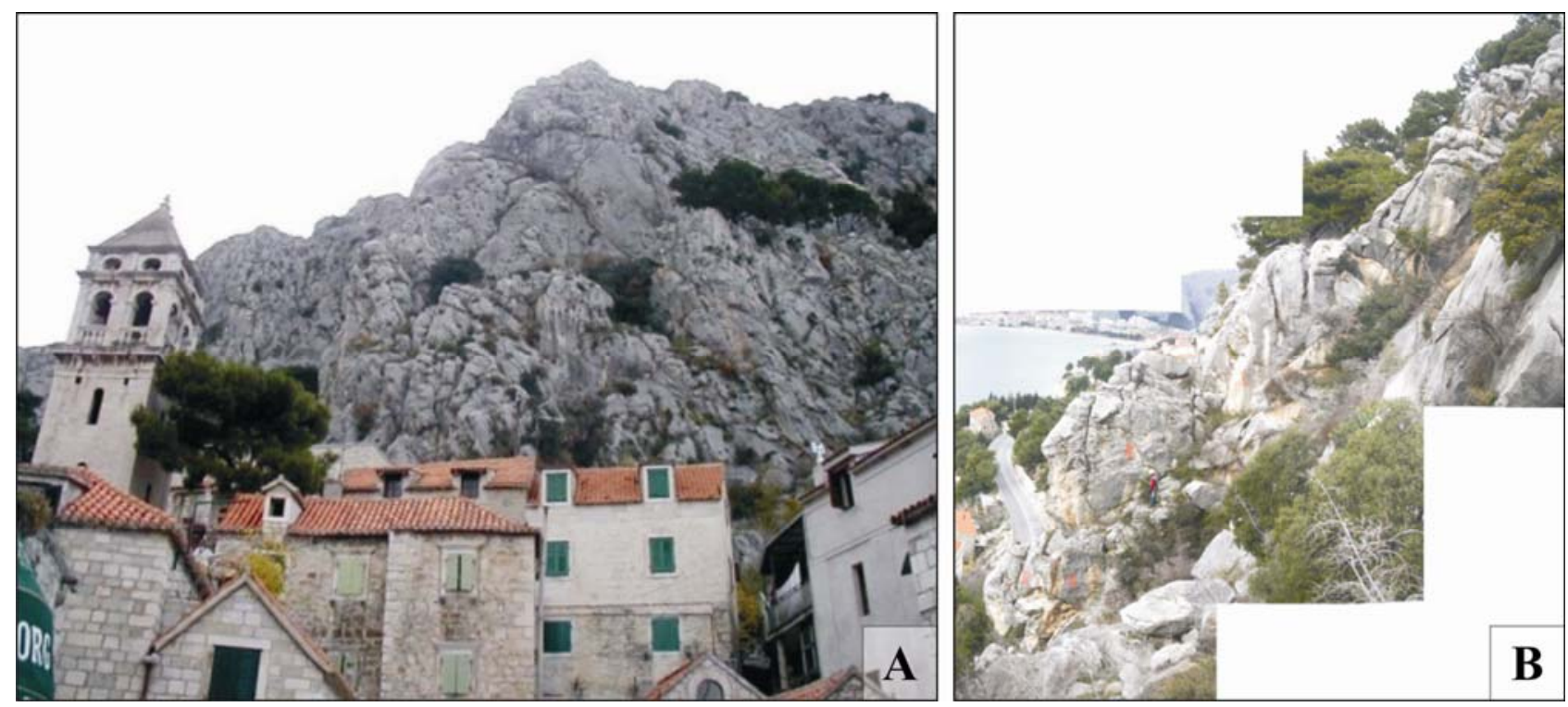

Fig. 3 Rockfall The rock slopes near the City of Omiš, Croatia. (A) Picture of the rock slopes above the City of Omiš. (B) A view of the rock slope below the Brzet Tunnel location and potentially unstable blocks.
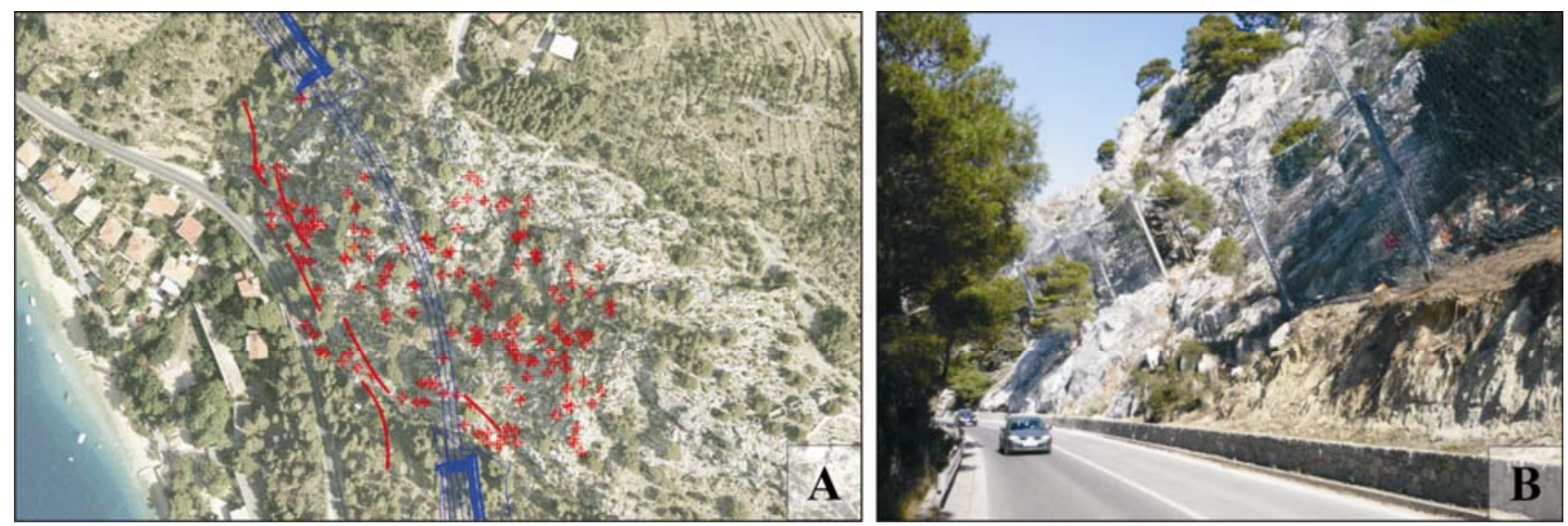

Fig. 4 Rockfall The rock slopes near the City of Omiš, Croatia. (A) Picture of the rock slopes above the City of Omiš. (B) A view of the rock slope below the Brzet Tunnel location and potentially unstable blocks.

simulations using the simulation software Rockfall 6.1 [26]. The rockfall simulation analyses simulated spherical and cylindrical $8.0 \mathrm{~m}^{3}$ big blocks falling from slope heights of 60 to $70 \mathrm{~m}$. Based on the rockfall simulation results, the rockfall protection barriers were selected (position of barriers, barrier energy class, length and height) (Fig. 4A).

The terrain was rated as a rough surface with a high friction dynamic and static angle. The damping factor is small to insignificant and has elastic characteristics. The rolling resistance and roughness are high and have a major influence on rockfall simulations.
As a result of the analyses, a system of protection barriers 7.5 to $8.0 \mathrm{~m}$ in height, with an energy-absorbing capacity of 3000 to $5000 \mathrm{~kJ}$, was used as the main structure for rockfall hazard protection (Fig. 4B).

Installation of the barriers was a demanding and dangerous job. Major parts of the installation were completed by alpinists and cranes. Work on the barrier installations and stabilizing blocks with bearing meshes and rockbolts were conducted between July and December of 2008 [27]. 


\section{Rockfall Protection Barriers at the Katarina Tunnel near the City of Rijeka}

During the construction of the Katarina Tunnel, a part of the Adriatic Motorway in an urban area of the city of Rijeka, a rockfall hazard was identified. The Katarina Tunnel is located on a very steep slope of limestone rock mass above the Zvir Spring, the main source of drinking water for the City of Rijeka and the surrounding urban area (Fig. 5A). The rockfall hazard consisted of the possibility of rock blocks detaching from the steep slope caused by blasting practices during tunnel and motorway cuts excavation, which can cause significant damages to the construction and facilities for water treatment in the toe of the slope. Another potential rockfall hazard was the possible movement of boulders and rock fragments on a talus slope surface with similar risk (Fig. 5B).

Based on engineering geological mapping data, a geotechnical model of the slope was established that pointed to unfavorable discontinuities of the limestone rock mass along future motorway cuts. The RMR rock mass classification was carried out, and the slope stability and stress-strain analyses were performed based on the obtained classification values of the rock mass. Results of the analyses confirmed the stability of the rock cuts without additional support system installation. Based on the identified characteristics of potentially unstable rock blocks, deterministic analyses of motion and the resulting pathways were performed. For the rockfall simulations, two-dimensional slope profiles were used. The profiles were divided into vertical slices with their own surface characteristics.

Sliding, rolling, toppling or the free fall of a block is possible as the initial movement after detaching and all possible types of subsequent movements were considered in the rockfall simulations. The rockfall simulations were carried out on the most critical profiles. The simulations were carried out as two-dimensional simulations using the simulation software Rockfall 6.1 [26], and the results of one of the simulations are presented in Fig. 6A. Bases on the analyses, rockfall protection using rockfall barriers were proposed and placed on the slope. At places where the energy was too high, barriers were placed in two lines because the installation of bigger barriers was not possible because of the rough and unapproachable installation field area.

The terrain was rated as a rough surface with high friction dynamics and static angle. The damping factor is small to insignificant and has elastic characteristics. The rolling resistance and roughness are high and have a major influence on the rockfall simulations. Although the rolling resistance was high because of significant roughness, it has a small influence because the slope is very steep, up to 48 degrees (Fig. 6A).
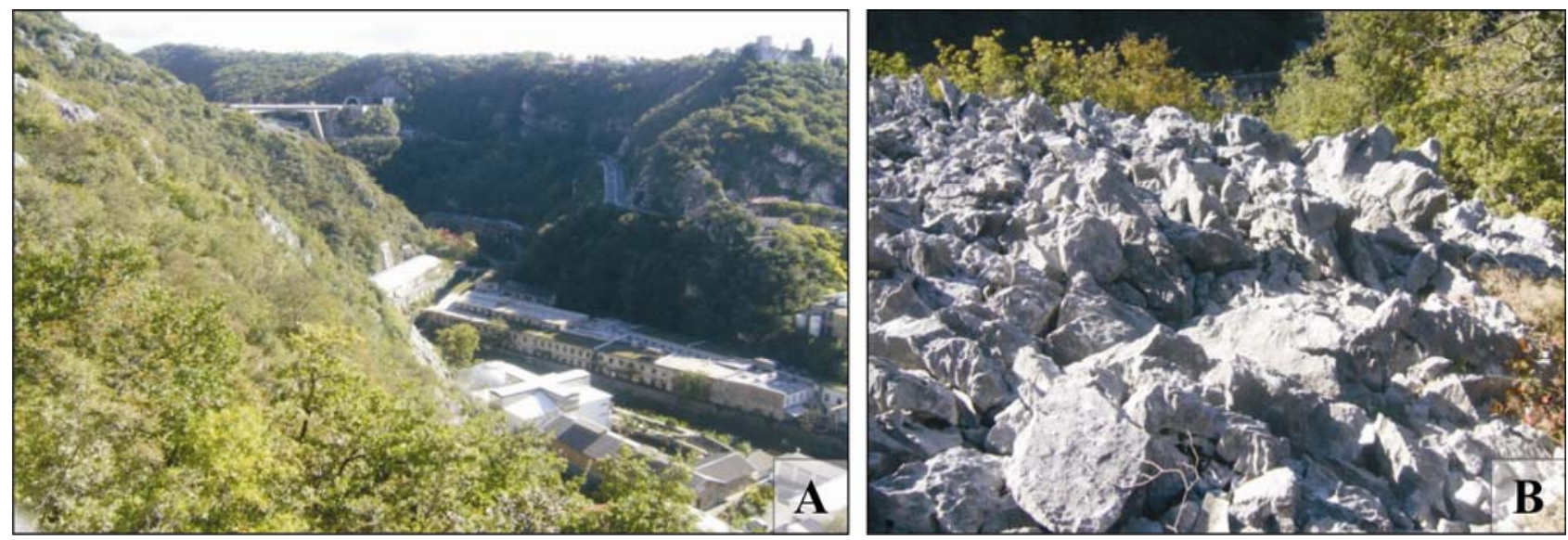

Fig. 5 (A) Picture of the Katarina Tunnel location. The buildings and facilities for Zvir Spring water treatment are visible at the toe of the slope. (B) Picture of the slope surface. 

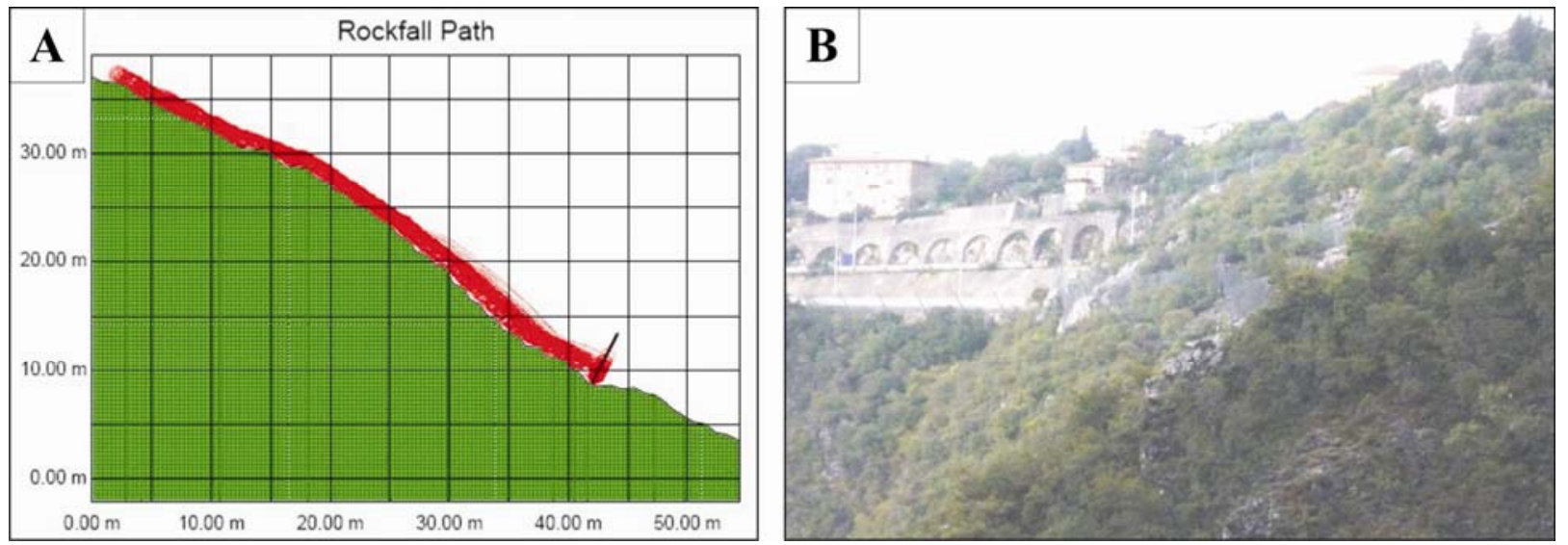

Fig. 6 (A) Rockfall simulation model. (B) Orthophotograph of the Katarina Tunnel location and the positions of the installed rockfall protection barriers.

The interactive design is applied throughout construction of the support system and includes high load-bearing meshes in combination with self-drilling rockbolts and rockfall protection barriers. As a result of the design, a system of 5-m-high Geobrugg's Spyder high load bearing nets [28] with an energy absorbing capacity of $1000 \mathrm{~kJ}$ and $4.5-\mathrm{m}$-high protection barriers [29] with an energy absorbing capacity of $500 \mathrm{~kJ}$ were used as the main structure for rockfall hazard protection (Fig. 6B).

The construction of the motorway was finished in June 2009. During the construction, two serious rockfalls occurred that were caused by rock cut excavation. All detached blocks were suspended by installed rockfall protection barriers [30].

\section{Rock Support System at the Banska Vrata Location near the City of Rijeka}

The Louisiana Road from the City of Rijeka to the City of Karlovac in Croatia was constructed between 1804 and 1815 and was one of the famous civil engineering achievements of the time. This road is still in use 200 years after construction without significantly recovering. The first part of the road was constructed on a very steep slope in the Rječina River canyon with high cuts in the limestone rock mass. The rockfall occurrences in recent years suggested that mitigation of the existing rockfall hazard using modern technologies of rockfall protection on the old road construction sites was required.
The rockfall analyses were carried out on locations where the rockfalls were registered in the winter of 2004. Based on engineering-geological mapping data, a geotechnical model of the slope was established that pointed to unfavorable discontinuities in the limestone rock mass and the possibility of further rockfall occurrences (Fig. 7). The rock mass rating (RMR) classification was carried out, and the global and local slope stability analyses were performed based on the obtained classification values of the rock mass. It was determined that possible toppling instability could occur, and it was necessary to design and apply appropriate measures to eliminate the existing rock fall hazard. The geological conditions and the system of discontinuities present in the cut were determined by the applied design approach. Removing potentially unstable rock mass blocks in the cut could cause relaxation of the rock mass in deeper zones of the cut, opening of new cracks with unfavorable orientation and retrogressive widening of the potentially unstable zone. Considering these circumstances, the classical rock support system was chosen, using rockbolts and reinforced shotcrete layers on the rock cut surface.

To confirm the efficiency of the support construction, stability analyses were carried out using the Geo Slope Slope/W software package [31], and the appropriate raster, capacity and length of the rockbolt was confirmed based on rock discontinuity parameters obtained from stability back analyses (Fig. 8A). 

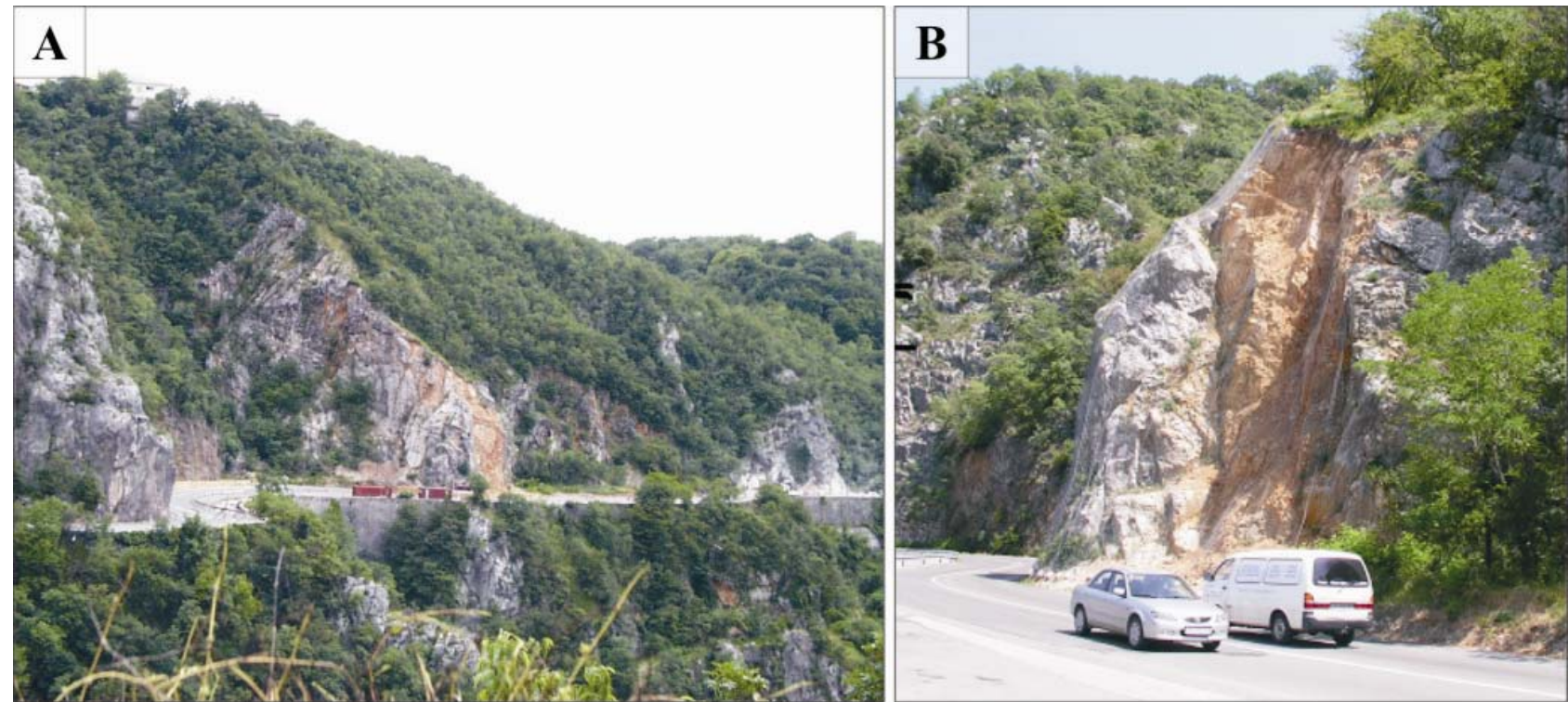

Fig. 7 (A) Rock cut at the Banska Vrata location on the Louisiana Road near Rijeka; (B) Rock cut and unstable rock blocks; toppling instability is possible.
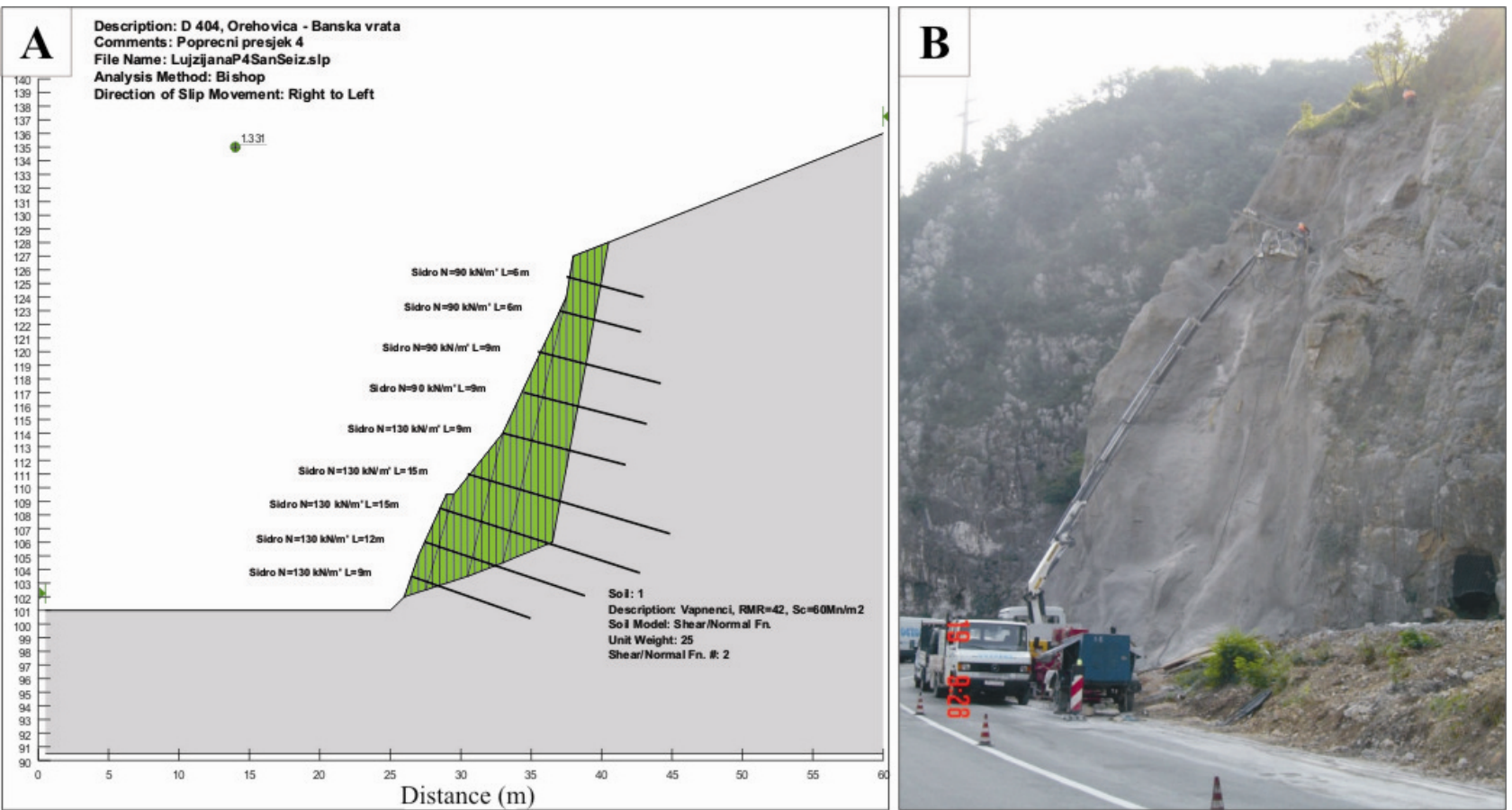

Fig. 8 (A) Geotechnical model and critical slip surface for possible instabilities along existing discontinuities, Banska Vrata location, Louisiana Road near Rijeka; (B) Rock cut during installation of rock support system.

Rock support construction was started and carried out in the summer of 2005 as a part of a rockfall hazard protection project along part of the Louisiana Road in the canyon of the Rječina River. This rock support installation (Fig. 8B) was one of the most demanding construction projects on the rock cuts in the City of
Rijeka area and relied on significant experience in rock cut protection.

\section{Discussion and Conclusions}

Investigations of rockfall hazards and rockfall hazard mitigation requirements in Croatia were increased during the last decade after large rockfall 
occurred on the steep limestone slopes along the Adriatic Coast of Croatia. These rockfalls caused injury to people and serious damage to buildings and traffic facilities. In recent years, a number of highways have been or are scheduled to be built in the coastal region of Croatia that carry significant risk of increasing rockfall hazard events. The rockfall events along the limestone slopes were caused by unfavorable rock mass characteristics during heavy rain periods and the influence of improper interventions in slopes during highway construction.

Numerous rockfall protection projects were conducted to ensure the protection of human lives and facilities from future rockfalls. The process of rockfall protection projects started with rockfall hazard analyses to identify the potential of rockfalls occurring and prevent potential consequences, i.e., risk.

Most of the rockfalls occurred on the engineered cuts and natural slopes near old roads. The consequences of these rockfalls induced a systematic approach to reduce or/and restrain the rockfall hazards. Old road slopes, where different types of rockfalls had been registered in the past, were subjected to rockfall hazard analyses, and on the basis of these analyses, rockfall protection projects were conducted. The significant advancement in rockfall hazard analysis and rockfall protection over the last ten years resulted from the design and construction of new roads and highways in Croatia. An appropriate rockfall hazard rating system incorporating local rockfall conditions in Croatia was never developed, and there are no official recommendations for rockfall hazard analysis. Under these circumstances, scientists and geotechnical engineers used existing rockfall hazard rating systems based on experiences from neighboring countries.

At the locations where hazards with related risk were determined, detailed field investigations were provided. Based on the indentified characteristics of potentially unstable rock mass blocks, analyses of the motion and resulting pathways were conducted. Rockfall trajectories, impact energy and height of bouncing depend on the slope geometry, slope surface roughness and rockfall block characteristics. Rockfall protection measures were designed based upon these analyses. Two design approaches were adopted: (1) prevention of rockfall by removing potentially unstable rock mass or by installing a rock mass support system; and (2) suspending the running rockfall mass with rockfall protection barriers.

In this paper, rockfall hazard determination, rockfall analyses and applied protection designs at three locations along the Adriatic coast of Croatia are presented. Rockfall protection projects using high-energy rockfall protection barriers were used during the construction of the Brzet Tunnel near the city of Omiš, the Katarina Tunnel near the city of Rijeka and the rock cut protection project on the old Louisiana Road near the city of Rijeka. The rockfall protection system designed and constructed at the Brzet Tunnel near the city of Omiš used a system of 7.5- to 8.0-m-high protection barriers with an energy absorbing capacity of 3000 to $5000 \mathrm{~kJ}$. It is one of the most dependable barrier systems in the world, and it is designed to suspend $8.0 \mathrm{~m}^{3}$ rock blocks falling from a 60 to $70 \mathrm{~m}$ slope and can suspend larger rock blocks, up to $20 \mathrm{~m}^{3}$, detached from lower parts of the slope.

\section{References}

[1] E. Hoek and J. Bray, Rock slope engineering, The Institute of Mining and Metallurgy, London, 1981.

[2] Z. H. Li, H. W. Huang, Y. D., Xue and J. Yin, Risk assessment of rockfall hazards on highways, Georisk 3 (2009) 147-154.

[3] C. O. Brawner, Rockfall hazard mitigation methods Participant Workbook, NHI Course No.13219. Publication No. FHWA SA-93-085. U.S. Department of Transportation, Federal Highway Administration, 1994.

[4] D. C. Wyllie, Risk management of rock fall hazards, Wyllie and Norish Rock Engineers, Seatlle, available online at: http://www.wnrockeng.com/presentations.html, 2006.

[5] P. Paronuzzi, Probabilistic approach for design optimization of rockfall protective barriers, Quaternary Journal of Engineering Geology 22 (1989) 175-183.

[6] T. J. Pfeiffer and T. Bowen, Computer simulation of rockfalls, Bulletin of Engineering Geology 26 (1989) 135-146. 
[7] T. J. Pfeiffer, J. D. Higgins, R. Schultz and R. D. Andrew, Colorado rockfall simulation program user's manual for version 2.1, Colorado Department of Transportation, Denver, 1991.

[8] E. Hoek, Practical Rock Engineering (2007 ed.), Rocscience, Toronto, available online at: http://www.rocscience.com, 2007.

[9] F. Guzzetti, G. Crosta, R. Detti and F. Agliardi, STONE: A computer program for the three-dimensional simulation of rockfalls, Computers and Geosciences 28 (2002) 1079-1093.

[10] R. Fell, K. K. S. Ho, S. Lacasse and E. Leroi, A framework for landslide risk assessment and management, in: International Conference on Landslide Risk Assessment and Management, Vancouver, BC, Canada, 2005.

[11] J. Corominas, R. Copons, J. Moya, J. M. Vilaplana, J. Altimir and J. Amigo, Quantitative assessment of the residual risk in a rockfall protected area, Landslides 2 (2005) 343-357.

[12] P. Budetta, Assessment of rockfall risk along roads, Natural Hazards and Earth System Sciences 4 (2004) 71-81.

[13] L. A. Pierson, S. A. Davis and R. Van Vickle, Rockfall hazard rating system - implementation manual, Federal Highway Administration (FHWA), Report FHWA-OR-EG-90-01. FHWA, U.S. Department. of Transportation, 1990.

[14] M. Romana, SMR classification, Proceedings of 7th International Congress on Rock Mechanics, Balkema, Rotterdam, 1991, pp. 955-960.

[15] Z. T. Bieniawski, Engineering Rock Mass Classifications, Wiley, New York, 1989.

[16] N. H. Maerz, A. Youssef and T. W. Fennessey, New risk-consequence rockfall hazard rating system for missouri highways using digital image analysis, Environmental \& Engineering Geoscience 11 (3) (2005) 229-249.

[17] A. M. Youssef, H. Norbert and N. H. Maerz, Slope stability hazard assessment and mitigation methodology along eastern desert aswan-cairo highway, Egypt, Earth Science 20 (2) (2009) 161-181.

[18] D. Bozzolo, R. Pamini and K. Hutter, Rockfall analysis - A mathematical model and its test with field data, in: Proceedings of 5th International symposium on Landslides, Lausanne, July 1988, pp. 555-560.

[19] O. Hungr and S. G. Evans, Engineering aspects of rockfall hazard in Canada, Geological Survey of Canada, Open File 2061, 1989.

[20] R. M. Spang and R. W. Rautenstrauch, Empirical and mathematical approaches to rockfall prediction and their practical applications, in: Proceedings of 5th International symposium on Landslides, Lausanne, July 1988, pp. 1237-1243.

[21] A. Azzoni, G. La Barbera and A. Zaninetti, Analysis and prediction of rockfalls using a mathematical model, International Journal of Rock Mechanics, Mining Science and Geomechanics Abstracts 32 (7) (1995) 709-724.

[22] D. C. Wyllie and N. I. Norrish, Stabilization of rock slopes. In: Turner AK, Schuster RL (eds.) Landslides: Investigation and mitigation. Special Report 247, Transportation Research Board, National Research Council, Washington, DC, 1996, pp. 474-504.

[23] D. C. Wyllie and C. W. Mah, Rock Slope Engineering, Civil and Mining (4th ed.), Spon Press, Taylor \& Francis Group, New York, 2004.

[24] I. Vlahović, J. Tišljar, I. Velić and D. Matičec, Evolution of the Adriatic Carbonate Platform: Palaeography, main events and depositional dynamics, Palaeography, Palaeocimatology, Palaeoecology 220 (2005) 333-360.

[25] D. Pollak, Influence of the Carbonate rock masses weathering on their engineering-geological properties, PhD Thesis, University of Zagreb, Faculty of Mining, Geology and Petroleum Engineering, Zagreb, 2007.

[26] R. M. Spang, Steinschlagsimultions programm Rockfall 6.1, Dr. Spang, Witten, 2001.

[27] M. Grošić, Ž. Arbanas and D. Udovič, Designing and Constructing Rockfall Barriers - Experiences in Republic of Croatia, in: I. Vrkljan (ed.), Proceedings of the Regional Symposium of the International Society for Rock Mechanics, Eurock 2009, Rock Engineering in Difficult Ground Conditions - Soft Rock and Karst, 29-31 October, 2009, Dubrovnik-Cavtat, Croatia, CRC Press/Balkema, Taylor \& Francis Group, Leiden, pp. 703-708.

[28] A. G. Geobrug, Protection systems technical data, Geobrugg, Romanshorn, available online at: http://www.geobrugg.com, 2008.

[29] A. Vogel, A. Volkwein, W. Gerber and A. Roth, Rockfall protection 2008: Flexible rockfall barriers subjected to extreme loads as high-speed rockfalls or falling trees, Interdisciplinary Workshop on Rockfall Protection. Morschach, Switzerland, WSL, Federale de Lausanne, Swiss Federal Institute of Technology, Zurich, 2008.

[30] D. Udovič, M. Grošić and Ž. Arbanas, Stabilization of extremely fractured rock mass with high load bearing meshes and rockfall barriers on the tunnel Katarina, Croatia, in: Proceedings of Geobrugg Slope Stabilization Europe East Conference, Krakow, Poland, October 2010 (in press).

[31] GEOSlope Int. Ltd., User's Guide Slope/W for Slope Stability Analysis, Version 4, GEOSlope, Calgary, 1998. 